light of the distinction between fair-mindedness and neutrality, it seems more reasonable to leave open more possibilities. But, as Wainwright observes, one's attitudes to opening or foreclosing possibilities may be influenced by how one weighs the different injunctions to believe the truth or to shun error (p. 91).

I hope to have conveyed some of richness of Wainwright's discussion. Wainwright articulates a view of reason according to which reason allows for more possibilities than the agnostic professes. One ongoing concern about the proliferation of possibilities - letting a thousand flowers bloom - is the difficulty of comparative judgments of plausibility. If Wainwright's view is correct then it seems to imply that reason is unable to significantly compare the plausibility of competing hypotheses in a non-question begging fashion. Yet, it may be that reason does not demand paying the cost of foreclosing possibilities.

\title{
AKU VISALA
}

University of Notre Dame, IN.

\section{Randal Rauser, Theology in Search of Foundation, Oxford University Press, 2009.}

Randal Rauser's Theology in Search of Foundation (OUP 2009, henceforth TSF) is the latest addition to the philosophical literature on the epistemology of theology. In recent years, there has been more and more talk about something called analytic theology. It is not perfectly clear what analytic theology is, but it seems appropriate to understand it as a movement in philosophical theology and philosophy of religion, which encourages and supports the use of analytic philosophical tools to treat questions that have traditionally been understood as theological rather than philosophical (e.g., Trinity, Christology, Incarnation, etc.). Furthermore, analytic theology, it seems, attempts to be a reforming movement of theological method - an attempt to free theology from its "continental captivity". As philosophers of religion go, most of the issues that TSF discusses are somewhat familiar, whereas for contemporary theologians, the topics might seem rather weird. If Rauser's approach to theology seems perplexing, the reader should consult Michael Rea's opening essay to a recent edited volume Analytic Theology: New Essays in the Philosophy of Theology (2009). 
The basic question for TSF is the justification of theology. Does theology need to justify its propositions in front of the court of universal reason, independent of culture and tradition, or should theologians forget the search for universal foundation and simply settle for coherence of the Christian tradition? It might come as a surprise to philosophers but during the last 50 years theologians have debated these issues viscerally and whole theological schools have been formed on the basis of such debates (the so called post liberal theology and Radical Orthodoxy, for instance). What might be surprising to theologians is that analytic philosophers have developed distinct answers to such epistemological problems in the last 30 years.

TSF is more a rigorous critique of various non-foundationalist or post-foundationalist approaches to theology rather than a detailed exposition of an alternative view. Rauser discusses the work of several contemporary theologians like Stanley Grenz, Nancey Murphy, Kevin Vanhoozer and Bruce Marshall as well as non-foundationalist philosophers such as Richard Rorty, W. V. O. Quine, Hilary Putnam and Donald Davidson on whom non-foundationalist theologians rely. For philosophers, the epistemological and metaphysical arguments that Rauser discusses (e.g., theories of truth, language and reality, realism and anti-realism) are probably familiar. What might be less familiar is the context of the theological debate. For understanding the theological context of TSF, the reader should consult Olli-Pekka Vainio's Beyond Fideism (Ashgate, 2010) which provides an overview of the debates on (post)modern theological method.

According to Rauser, the story of justifying theology goes something like this. Before the 17th century and the advent of classical foundationalism, theology was not particularly concerned about justifying itself in any universal sense. After the Reformation, the emergence of modern science and post-Reformation political tumults in Europe, a new standard for justification was formed. This was classical foundationalism. In Rauser's own words, classical foundationalism is the view that for all b's (justified belief): 'Every b is either (1) properly basic - that is, $b$ is either a self-evident intuition or an incorrigible sense experience - or (2) non-basic - that is, it is ultimately deduced or inferred from beliefs that are properly basic and the individual is aware of how b derives from properly basic belief.' (p. 84) In other words, on classical foundationalism there are basic beliefs that need not be justified by other beliefs and our knowledge of the basic beliefs is infallible or certain. 
Non-basic beliefs are then justified on the basis of these infallible basic beliefs. Classical foundationalism is also internalistic in the sense that the epistemic subject has access to the evidence that justifies her basic beliefs.

Now, theology had two options: either take the route of John Locke or various other Enlightenment natural theologians, or abandon the justificatory project altogether and ground theology on something nonepistemic, like religious experience or ethics (like Kant). As a side effect of the natural theological project, there were also attempts to ground theology on scriptural inerrancy. Rauser concludes that all these attempts were failures. The natural theologians were unable to produce arguments that would satisfy the rigorous standard of classical foundationalism. Similarly, Kantian attempts to justify theology in terms of ethics had a tremendous price: God as something distinct from our experience was completely lost.

But why hold onto the classical foundationalist theory of justification in the first place? Rauser is in agreement with contemporary nonfoundationalists that classical foundationalism should be abandoned. For one, most of the beliefs that seem certain to us on the surface are actually such that we can, at least in principle if not in practice, doubt. After Cartesian evil demons, it seems very difficult to ascribe absolute certainty to most beliefs outside logical and mathematical beliefs. The beliefs that matter to us the most (commonsense empirical beliefs and moral beliefs, for instance) fall prey to this lack of certainty.

Classical foundationalism is also challenged by the linguistic thesis according to which all experience is linguistically mediated. The classical foundationalist has to assume that there is some sort of pure, nonconceptual experience (like in the sense-data theory) that will then justify our basic beliefs. But if our basic perceptions are grounded in concepts that are, in turn, shaped by our linguistic community, basic beliefs lose their incorrigible grounding in reality. Our language becomes a kind of world in which we live without the possibility of 'stepping outside our language to see how things really are'.

Finally, there is the famous argument that classical foundationalism is incoherent. Remember that on classical foundationalism we have properly basic beliefs that are either a priori true or a posteriori infallible. Is the belief that classical foundationalism is true properly basic or not? It does seem to be either a priori self-evident nor a clear empirical truth. 
If this is the case, belief in classical foundationalism itself is not justified given the classical foundationalist criteria for justification.

Such critiques of classical foundationalism lead to fallibilism, the view that there are no absolutely certain beliefs. As a consequence, some philosophers (such as Rorty, Quine and Davidson) and most theologians have abandoned foundationalism completely and attempted to ground theology on coherentism instead. On coherentism, there are no basic beliefs, since the view entails that only beliefs justify beliefs. On foundationalism, knowledge comes as structure in which basic beliefs are at the bottom. On coherentism, the most apt metaphor is a web in which each belief provides justification for another. Furthermore, most non-foundationalist theologians also accept the linguistic thesis, which usually leads to metaphysical anti-realism (no mind-independent world or we cannot say anything about it) and alethic agnosticism or antirealism (rejection of the correspondence theory of truth).

Rauser identifies numerous problems in the non-foundationalist proposals. First, Rauser challenges the thoroughgoing fallibilism of the non-foundationalist. This is because the claim that all beliefs are revisable in the light of new experiences leads to scepticism. He agrees with the non-foundationalists that most of our beliefs are indeed fallible, but he nevertheless maintains that there are some analytic (or synthetic a priori) truths that have to do with definitions, logic and mathematics. Beliefs about such truths must be a priori, because there is nothing in our experience that justifies them. Why should we not abandon them then? Defenders of radical non-foundationalism, such as Quine, give no argument as to why we should hold onto the truth of, say, the law of non-contradiction. The conclusion Rauser draws from this is that not every belief is accountable and revisable in the light of new experiences, as the non-foundationalist would have it. This does not mean that our knowledge of such analytic truths is infallible: we might make mistakes in accessing such truths but that does not mean that they are not there. There is something more to belief-formation than experience alone.

TSF also points out that coherentism is subject to various counterarguments. The problem is that coherence seems to be only one possible mark of true beliefs, not the only one. Imagine that you are working at your office, when you are suddenly hit in the head. Due to some strange misfiring in your brain, you still keep having the sensation of being in your office and believing that you see a computer in front of you. But in truth, you have actually been taken to the hospital and most of your 
beliefs are false. In this case your beliefs would be coherent, but we would be extremely hesitant to say that they would be justified. Instead, we would say that they are not justified, because after the lighting strike and neural misfiring they have been produced in a mistaken manner, that is, in a manner that is not reliable. So it seems that coherence might be one mark of truth-conduciveness, but neither a necessary nor a sufficient mark all by itself. Instead, the most important mark for truth and guideline for justification would be reliability of the belief-forming mechanism.

Rauser also finds the linguistic thesis problematic. There is a non sequitur deep in the argument for the linguistic thesis. The proponent of the thesis argues that since concepts are needed to talk about our experience of the world, the experiences themselves must be conceptually conditioned. But this does not follow. In the case of perceptual knowledge, I am being presented by numerous facts about my environment. For example, all the different shades of colour on my computer display are presented to me at the same time. This does not mean, however, that we need to have corresponding colour concepts to have such experiences. In other words, we can experience the properties of our environment without grasping the associated concept. Such a view would entail a direct realist view of perception and other sources of basic beliefs (reason, memory): our beliefs that are composed of our basic concepts can be grounded directly in our basic perceivings. As such, the theory entails that there are concepts that have a natural, intrinsic connection with the properties exemplified by the world. Thus, language is not a world in which we live, a veil between the world and ourselves; it does not determine our experience of the world. Instead, language is a tool to conceptualize and talk about the world to which we all perceive.

TSF also defends a strong metaphysical realism and claims that realism is not one theory among many but a necessary precondition for talking about truth, language and related concepts. Constitutive antirealism sees the 'real word' as a kind of undetermined flux that only takes determinate shape when we carve it into categories with our concepts. The problem is that incoherence looms: if the real world is constituted by our concepts, the claim that the world in constituted by our concepts is also constituted by our concepts and so on ad infinitum. TSF concludes that there are no viable alternatives to minimal metaphysical realism, that is, the thesis that there is a mind-independent world. 
Rauser suggests an alternative to the problematic forms of nonfoundationalism: return to a moderate foundationalism, hold onto a robust realism about metaphysics and truth and reject the linguistic thesis. His model draws heavily on the epistemology of Alvin Plantinga and other Reformed epistemologists, like William Alston.

Plantinga's epistemology is foundationalist, because it holds onto the idea that there are beliefs that are not justified by other beliefs. The difference to classical foundationalism is that the justification of these basic beliefs is fallible and defeasible. This is because even basic beliefs are subject to various sorts of defeaters, that is, new evidence that removes the prima facie justification that basic beliefs have. Furthermore, Plantinga's view entails that basic beliefs are products of properly functioning belief-forming systems and it is the trustworthiness of these systems that makes basic beliefs justified. Plantinga takes his cue from Thomas Reid, a contemporary and opponent of Locke. Reid maintained that we have beliefs that are innocent until proven guilty, that is, they need no propositional evidence to be justified. It is enough that they are products of normally functioning belief-forming mechanisms (perception, reasoning, memory). Further, Reid maintained that if we go on to demand propositional, non-circular evidence for the reliability of our basic belief-forming mechanisms, we end up in scepticism. This is the externalist component of Plantinga's view: the epistemic subject is not required to have access to the propositional evidence (other beliefs) to be entitled to hold onto her basic beliefs.

Plantinga's defence of externalism requires that our belief-forming faculties are, for the most part, reliable sources of beliefs, that is, they are truth-conducive in the correct circumstances. Plantinga understands reliability in terms of proper functioning. Proper functionalism of this kind entails that there is a design plan for our belief-forming faculties: our belief-forming faculties emerged according to the plan of a being who can guarantee that they are truth-conducive, because the being itself is infallible (God). As is well known, this is the starting point of Plantinga's evolutionary argument against naturalism that seeks to show the unreliability of our belief-forming mechanism, if they had evolved without God's guidance. The latest version of the argument can be found from Plantinga's Where the Conflict Really Lies: Science, Religion and Naturalism (OUP, 2011).

In his later work Warranted Christian Belief (OUP, 2000), Plantinga goes on to develop his Aquinas/Calvin model of theological beliefs. 
On this view, basic theological claims derive from normally functioning cognitive systems in natural environments. There is a specific cognitive mechanism, sensus divinitatis that is designed for just this purpose. As such, properly basic Christian beliefs need no external warrant to be rational; theological claims need not be grounded in incorrigible a priori truths or indubitable empirical evidence. But this does not mean that evidence is completely irrelevant, since it can function as defeater to properly basic belief derived from sensus divinitatis.

In addition to Plantinga-style proper functionalism and metaphysical and alethic realism, Rauser defends a cognitive-propositional view of dogma. On the cognitive-propositional view, (most) doctrinal statements are statements about mind-independent reality and it is that reality that makes them true or false. In other words, doctrinal statements refer to matters of fact; they are not expressions of or references to basic religious experiences (experiential-expressivist model), nor are they rules of speaking and acting in Christian communities (cultural-linguistic model). The worry that accompanies the critiques of the cognitivepropositional view is that it leads to a static view of the dogma and leaves no room for development, especially in the context of ecumenical theology. Such criticisms, according to Rauser, are misguided: like in critical realism in science, the fact that we understand propositions as referring to mind-independent realities does not mean that the propositions we now believe are the most truth-like that we could have.

I often complain that the books that I review are too long. TSF is a surprising exception: for once, I can say that the book under review was too short. Many arguments in TSF, especially in the middle of the book discussing Quine and Putnam and others, are to the point but too dense. I wish Rauser had used more pages to explain what these authors say and what his own critical points are. The arguments and counterarguments are there even now but they are discussed in a machine gun -like fashion that is rather difficult to follow, if the arguments are not already familiar to the reader. Also, the discussion of Plantinga's epistemology is clear and accurate but does not really discuss the various well-known criticisms of Plantinga's epistemology. If Rauser wants to convince us that we should embark upon an exodus from the slavery of non-foundationalism to the Plantingian Promised Land, he ought to have addressed at least the central objections to Reformed Epistemology.

Another thing that was missing from Rauser's book was a discussion on current internalist and evidentialist theories in philosophy of religion 
and philosophical theology. There are surprisingly many who adopt an internalist theory of justification along the lines of Richard Swinburne (Epistemic Justification, OUP, 2001) and reject the proper functionalism of Plantinga. The only time Swinburne is even mentioned in TSF is in the context of Enlightenment style natural theology, where he is swiftly brushed aside. Indeed, almost all theologians reject Swinburnestyle natural theology and even make fun of it. Nevertheless, Rauser is too quick in identifying Swinburne-style natural theology with Enlightenment natural theology: Swinburne's model does not require there being incorrigible basic beliefs.

It is true that broadly speaking externalist approaches to knowledge are common in contemporary epistemology. According to a recent survey of philosophical views, around 40\% of contemporary philosophers accept or lean towards externalism. However, Swinburne is hardly a deviant in the context of contemporary philosophical epistemology in which Bayesian and other broadly speaking internalist/evidentialist approaches are still very much alive. According to the same survey, internalism is either accepted or sympathized with by $26 \%$ of philosophers. In the last couple of years, there have been numerous debates about and defences of internalism by, for example, Earl Conee \& Richard Feldman (Evidentialism, OUP, 2011) and several others (Trent Dougherty, ed., Evidentialism and Its Discontents, OUP, 2011). This applies to both atheists and theists: some atheists, like Herman Phillipse (God in an Age of Science, OUP, 2012) adopt an even more uncompromising internalism and evidentialism than Swinburne.

Most philosophers of religion and philosophical theologians are already critical of non-foundationalist epistemologies and theological anti-realism - without any help from Rauser. For them, the choice is between Swinburne-type internalism, Plantinga-style externalism, some sort of virtue epistemology or a non-standard combination thereof (e.g., Paul Moser's The Evidence for God: Religious Knowledge Reexamined, CUP, 2009). For this reason, I would have liked to see Rauser engage with internalism in philosophy of religion more.

Finally, I want to make my last critical point. As we have seen, Rauser's model relies heavily on Reformed Epistemology in general and Plantinga in particular. But Plantinga and his cohorts are not the only ones to defend moderate foundationalism. Here, I think, Rauser could have made his model more appealing by discussing other moderate foundationalist proposals. Rauser often refers to Robert Audi (Epistemology, Routledge, 
2002) but does not mention that Audi has his own version of moderate foundationalism that is different from Plantinga's. After the publication of TSF, Audi has developed his model in the context of theological epistemology in his Reason and Religious Commitment (OUP, 2011). Audi's moderate foundationalism might be a serious option for those who are not too keen on the proper functionalism of Plantinga.

In conclusion, I admit that although I am not sure whether I identify myself directly with the analytic theology movement, I very much sympathize with the approach that it represents and find myself agreeing with most of what TSF says, especially with the critiques of various nonfoundationalist theologies and the accompanying robust theological realism. TSF splendidly identifies and analyzes the deep philosophical issues inherent in theological proposals. As for the attempt to ground theology in Plantinga-style proper functionalism, I am not that sure. Despite my worries about Rauser's own solution and his limited discussion of current internalist proposals, I wholeheartedly recommend the book to theologians that are interested in the epistemology of theology as well as to philosophers that are thinking about theology and theological method. That being said, I would not direct theological and philosophical novices to the book, because of the density of its arguments and the need for extensive background knowledge for understanding it.

\section{SCOTT DAVISON}

\section{Morehead State University}

\section{Vincent Brümmer, What Are We Doing When We Pray?: On Prayer and the Nature of Faith, Ashgate, 2008.}

This is a revised and expanded version of a book originally published by the author in 1984. Part I, which concerns prayer in the Christian tradition, takes up the first seven chapters of the book, and Part II, which concerns the nature of Christian faith, takes up the final three chapters. Here I shall summarize briefly the contents of each chapter before making some general remarks about the audience to whom this book is most likely to be useful.

Chapter 1 outlines the questions to be discussed in the book, including some methodological ones about how to study the phenomenon of 